\author{
Claude Grégoire \\ Lionel Chasson \\ Carmelo Luci \\ Elena Tomasello \\ Frédéric Geissmann \\ Eric Vivier \\ Thierry Walzer
}

\title{
The trafficking of natural killer cells
}

\author{
Authors' address \\ Claude Grégoire ${ }^{1,2,3}$, Lionel Chasson ${ }^{1,2,3}$, Carmelo Luci ${ }^{1,2,3}$, \\ Elena Tomasello ${ }^{1,2,3}$, Frédéric Geissmann ${ }^{4}$, Eric Vivier ${ }^{1,2,3,5 *}$, \\ Thierry Walzer ${ }^{1,2,3 *}$ \\ ${ }^{1}$ Centre d'Immunologie de Marseille-Luminy, Université \\ de la Méditerranée, Marseille, France. \\ ${ }^{2}$ INSERM, U631, Marseille, France. \\ ${ }^{3}$ CNRS, UMR6102, Marseille, France. \\ ${ }^{4}$ INSERM U838, Hôpital Necker-Enfants Malades, Faculté \\ de médecine de l'Université Paris Descartes, Paris, France. \\ ${ }^{5}$ Hôpital de la Conception, Assistance Publique-Hôpitaux \\ de Marseille, Marseille, France \\ *Eric Vivier and Thierry Walzer share senior authorship. \\ Correspondence to: \\ Thierry Walzer \\ Centre d'Immunologie de Marseille-Luminy (CIML) \\ CNRS-INSERM-Université de la Méditerranée Campus de \\ Luminy, Case 906, 13288 Marseille Cedex 09 \\ France \\ Tel.: +33491269493 \\ Fax: +33491269430 \\ e-mail: walzer@ciml.univ-mrs.fr \\ Acknowledgements \\ The authors thank the mouse functional genomics \\ platform of the Marseille-Nice Genopole ${ }^{\circledR}$ for \\ immunohistochemistry and Marc Barad et Mathieu Fallet \\ for help with confocal microscopy. The E. V. lab is \\ supported by European Union FP6, LSHB-CT-2004- \\ 503319-Allostem, Ligue Nationale contre le Cancer \\ ('Equipe labellisée La Ligue'), Agence Nationale de la \\ Recherche ('Réseau Innovation Biotechnologies' and \\ 'Microbiologie Immunologie - Maladies Emergentes'), \\ INSERM, CNRS, and Ministère de l'Enseignement \\ Supérieur et de la Recherche. C. L. is supported by \\ Fondation pour la Recherche Médicale.
}

Immunological Reviews 2007

Vol. 220: 169-182

Printed in Singapore. All rights reserved

(C) 2007 The Authors

Journal compilation (C) 2007 Blackwell Munksgaard

Immunological Reviews

0105-2896
Summary: Natural killer (NK) cells are large granular lymphocytes of the innate immune system that participate in the early control of microbial infections and cancer. NK cells can induce the death of autologous cells undergoing various forms of stress, recognizing and providing nonmicrobial 'danger' signals to the immune system. NK cells are widely distributed in lymphoid and non-lymphoid organs. NK cell precursors originate from the bone marrow and go through a complex maturation process that leads to the acquisition of their effector functions, to changes in their expression of integrins and chemotactic receptors, and to their redistribution from the bone marrow and lymph nodes to blood, spleen, liver, and lung. Here, we describe the tissue localization of NK cells, using NKp46 as an NK cell marker, and review the current knowledge on the mechanisms that govern their trafficking in humans and in mice.

Keywords: innate immunity, anatomy of the immune system, natural killer cells

\section{Introduction}

Natural killer (NK) cells are lymphocytes of the innate immune system that can induce the death of allogeneic cells and autologous cells undergoing various forms of stress, such as upon microbial infection and malignant transformation $(1,2)$. NK cells express an array of activating and inhibitory receptors, whose engagement allows them to discriminate between target and non-target cells (3-5). The repertoire of NK cell receptors complements that of other innate sensors, such as scavanger receptors, Toll-like receptors (TLRs) or nucleotide oligomerization domain (NOD) proteins. The strategies of NK cell recognition thus broaden the detection of pathogenic situations where microbial 'danger signals' are missing in vivo, such as in the case of poorly immunogenic tumors.

Consistent with their role in immune surveillance, NK cells are widely distributed in the body. It is unclear, however, whether this wide distribution is due to their recirculation, due to the existence of NK subsets with different homing capacities, or due to their development at multiples sites. NK cells can also be recruited in various tissues upon inflammation. However, in contrast to B and $\mathrm{T}$ cells, the mechanisms governing NK cell trafficking remain poorly dissected. 


\section{NK cellwide tissue distribution}

It has been long appreciated that NK cells are widely distributed in mammals (6). However, few studies have precisely addressed this distribution. An early study in rat showed that the frequency of large granular lymphocytes (LGLs), including NK and T-cell subsets, was high in the lung and peripheral blood, superior to that in the spleen, peritoneal exudates, and lymph nodes. LGLs were also found to be absent in the thymus and bone marrow (7). Subsequent studies in the mouse have shown the presence of NK cells, defined as NK1.1 ${ }^{+} \mathrm{CD}^{-}{ }^{-}$or $\mathrm{DXS}{ }^{+} \mathrm{CD} 3{ }^{-}$by flow cytometry, in various organs but never focused on their distribution (8). We revisited this question and measured the percentage and number of mouse NK cells in various organs. Our results confirmed the wide distribution of NK cells in lymphoid and non-lymphoid organs (Fig. 1). The frequency of NK cells in lymphocytes was found to be the highest in non-lymphoid organs such as the lung and liver. A similar phenomenon has also been observed for effector memory $\mathrm{CD} 8^{+} \mathrm{T}$ cells (9), suggesting similar mechanisms of trafficking for these two cell types and the existence of a niche for interleukin-15 (IL-15)dependent lymphocytes in non-lymphoid organs. The order for
NK cell frequency is lung $>$ liver $>$ peripheral blood mononuclear cells $(\mathrm{PBMCs})>$ spleen $>$ bone marrow $(\mathrm{BM})>$ lymph node (LN) $>$ thymus, where NK cells are almost undetectable. For comparison, NK1.1 ${ }^{+} \mathrm{T}$ cells predominate in the liver, while T cells prevail in blood and LN (Fig. 1). Human NK cells also appear to be frequent in non-lymphoid organs $(10,11)$.

The largest number of mouse NK cells, 2-3 million, can be found in the spleen. Significant reservoirs of NK cells may also be found in all other organs tested excluding the thymus (Fig. 1). In humans, it was found that lymph node NK cells outnumber blood NK cells by 10:1 (12), whereas an estimated 1:1 ratio was observed in the mouse. The reason for this discrepancy could be linked to the expression of CCR7 on a subset of human but not on mouse NK cells, as discussed later

The presence of NK cells in epithelial tissues has been poorly investigated. NK cell numbers are massively increased in the uterus during pregnancy both in humans and mice (13). In humans, $\mathrm{CD}^{-}{ }^{-} \mathrm{CD} 56^{+} \mathrm{NK}$ cells have been detected in the skin of healthy donors (14) and in the lymph draining this tissue (15). An infiltration of NK cells has been reported in lesional atopic dermatitis skin, in both epidermis and dermis, after Malassezia exposure (16), and in the inflammatory skin during
A
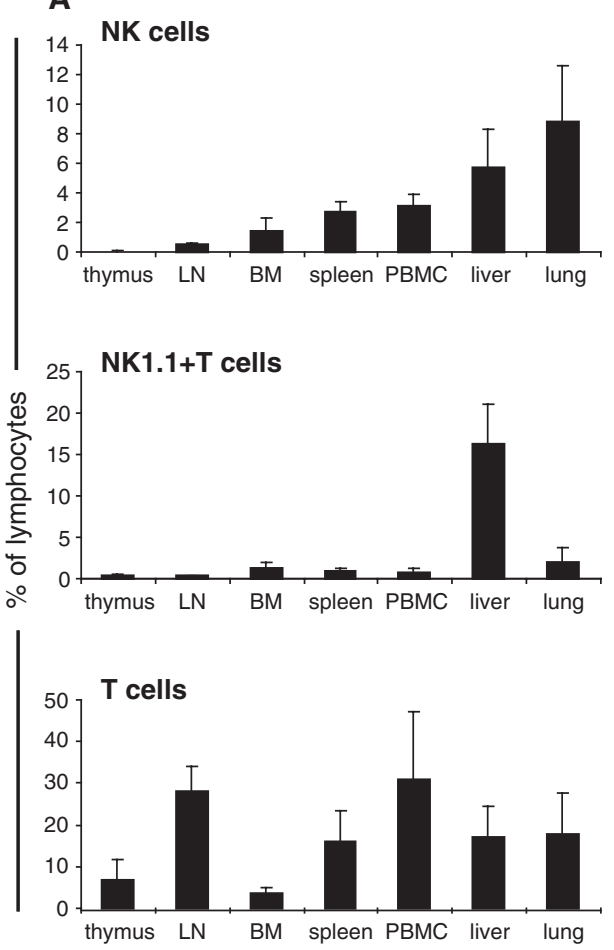

B

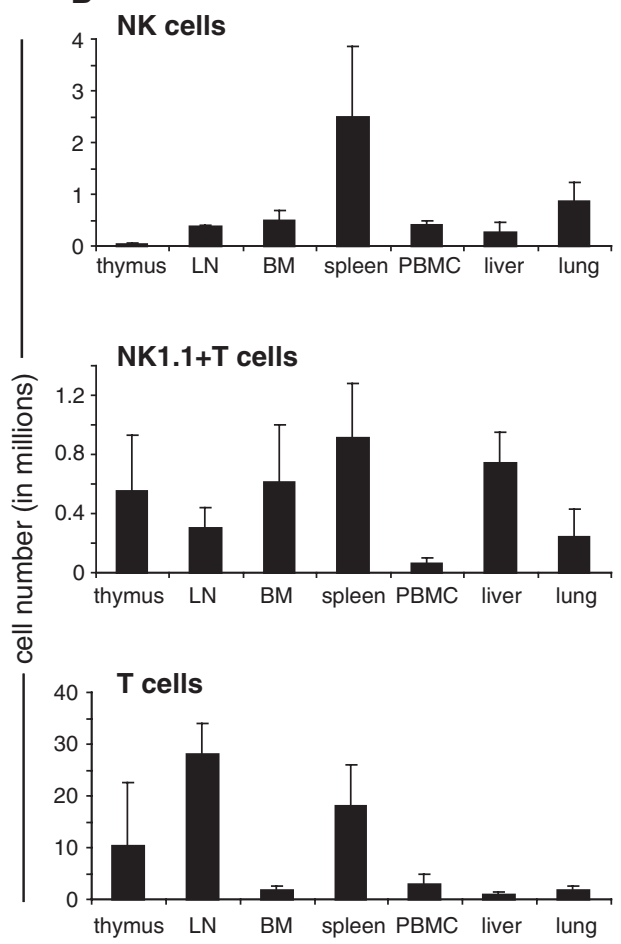

Fig. 1. Tissue distribution of natural killer (NK), NK1.1 ${ }^{+} \mathrm{T}$, and $\mathrm{T}$ cells. Lymphocyte populations were isolated from the indicated organs of $6-$ week-old C57BL/6 female mice, as previously described (33). (A) The percentage of NK1.1 ${ }^{+} \mathrm{CD} 3^{-}$(NK cells), NK1.1 ${ }^{+} \mathrm{CD} 3^{+}$(NK1.1 ${ }^{+} \mathrm{T}$ cells), and NK1.1 ${ }^{-} \mathrm{CD}^{+}$(mature T cells) cells was measured by flow cytometry. (B) Cell numbers of the indicated subsets were obtained by multiplying the respective frequency of each subset by the total number of lymphocytes in the organ. For blood and lymph nodes, we used an estimate number of 10 million cells in peripheral blood mononuclear cells and 100 million cells in LNs. Results show the mean \pm standard deviation (SD) of six mice for each organ. 
the elicitation phase of contact hypersensitivity in a mouse model of allergic contact dermatitis (17). Furthermore, several groups have reported an accumulation of cells expressing an NK cell phenotype in skin psoriatic lesions (18-20). However, further investigations are required to clearly determine whether infiltrating cells are 'true' NK cells or rather NK-like $\mathrm{T}$ cells. In a normal human intestine, $\mathrm{CD} 3^{-}$intraepithelial leukocytes expressing NK cell markers such as CD122, CD161, CD2, CD94, CD56, or CD16 have been described (21-24). Finally, CD3 ${ }^{-} \mathrm{NK} 1.1^{+}$cells have been recently identified in cell suspensions prepared from mouse vaginal tissue (25). Moreover, IL- $15^{-/-}$and/or RAG2 ${ }^{-/-} \gamma_{\mathrm{c}}^{-/-}$mice are more sensitive to genital herpes simplex virus 2 (HSV-2) infection, suggesting a potential implication of NK cells in the control of infection spreading in mucosal tissues $(26,27)$.

\section{NK cells in sinuses}

In situ visualization of NK cells has been hampered by the lack of specific reagents. Previous attempts to identify NK cells in situ were based on adoptive transfers of fluorescently labeled cells or staining with anti-NK1.1, anti-Ly49G2, or anti-CD49b (28-32). However, none of the aforementioned antibodies are NK cell specific (NK1.1, CD49b) or expressed on all NK cells (Ly49G2, CD49b). We recently described that the cell surface expression of the activating NK cell receptor NKp46 (CD336) defines at best NK cells across mammalian species, providing the opportunity to look at NK cells in situ on tissue sections using anti-NKp46 antibodies (33).

In the spleen, NK cells are mostly found in the red pulp at a steady state, thus excluded from the $\mathrm{T}$ and $\mathrm{B}$ lymphocyte-rich area (defined by CD3 and CD19 staining) (Fig. 2A).

Staining for metallophilic macrophages [sialoadhesin (Sn)] (Fig. 2B) and marginal zone macrophages (SignR1) (Fig. 2C) reveals that a few NK cells are also present in the marginal zone but do not go beyond this zone toward the white pulp. Antibodies to NKp46 and CD31 [platelet-endothelial cell adhesion molecule-1 (PECAM-1), an endothelial marker] stain the same regions, suggesting that most splenic NK cells are in fact located inside blood sinuses (Fig. 2D). Occasional NKp46 ${ }^{+}$cells are found in the white pulp, but staining for CD31 suggests that many of them are in fact located within sinuses or vessels (Fig. 2D). Many other cell types can be found in the vicinity of the "NK cell zone'. In particular, most $\mathrm{CD} 11 \mathrm{~b}^{\text {high }}$ cells (including macrophages) (Fig. 2E) are found in the red pulp and the marginal zone, whereas many $\mathrm{CD} 11 \mathrm{c}^{\text {high }}$ cells (including dendritic cells) (Fig. 2F) are found not only in the white pulp but also in the marginal zone and the red pulp. Cell-cell contacts between NK cells and macrophages (either of the red pulp or of the marginal zone) can be seen on these static images. These observations support the existence of interactions between NK cells and macrophages, as well as NK cells and dendritic cells. Such interactions have been extensively documented in vitro (34-37) and lead to the mutual regulation of these different cell types in the orchestration of immune responses.

At a steady state, NK cells are also found in the peripheral LN, mostly excluded from T- and B-cell zones (33, authors' unpublished data), consistent with previous studies (29). NK cells are found in perifollicular regions, in the paracortex, and especially in the medulla zone within lymphatic sinuses (29). In the perifollicular region, NK cells are found again in sinuses surrounding the follicles and especially between these follicles, at the site where presumably dendritic cells migrating from tissues arrive to the draining LN through an afferent lymph (29).

Within secondary lymphoid organs, the three types of lymphocytes (T, B, and NK cells) thus localize in distinct compartments. NK cells are preferentially found inside vessels or sinuses, either blood or lymphatics. The same conclusion could also be reached for the liver, as it is known that most hepatic lymphocytes are present in the sinusoids (38) and are absent from the parenchymal space.

\section{NK cell development and maturation}

Compelling evidence points to the BM as the primary site of NK cell development in adults at a steady state (6). Moreover, recent articles suggested that LN and thymus could be alternative sources of $\mathrm{NK}$ cells $(39,40)$. The relative contribution of these organs to the pool of NK cells is not known but is expected to be low at a steady state. Indeed, this extramedullary 'NK-poiesis' appears to produce phenotypically distinct NK cells, expressing the $\alpha$ chain of the IL-7 receptor (40). Such NK cells make up $<5 \%$ of the total NK cells. Moreover, a careful examination of thymic NK cells reveals that many of them express CD3 intracellularly and share phenotypic and functional features with NK1.1 ${ }^{+} \mathrm{T}$ cells, suggesting that they are in fact NK-like T cells (41). However, in mice where Tcell development is blocked by genetic means, a very high number of NK cells develop in the thymus, showing the ability of T-cell precursors to develop into NK cells under particular conditions (40). Furthermore, the normal liver contains a substantial number of immature NK cells, suggesting that NK cell precursors originating in the BM could seed the periphery and develop in situ (42). Thus, it is possible that extramedullary NK cell development may take place under lymphopenic or other conditions that remain to be dissected. 

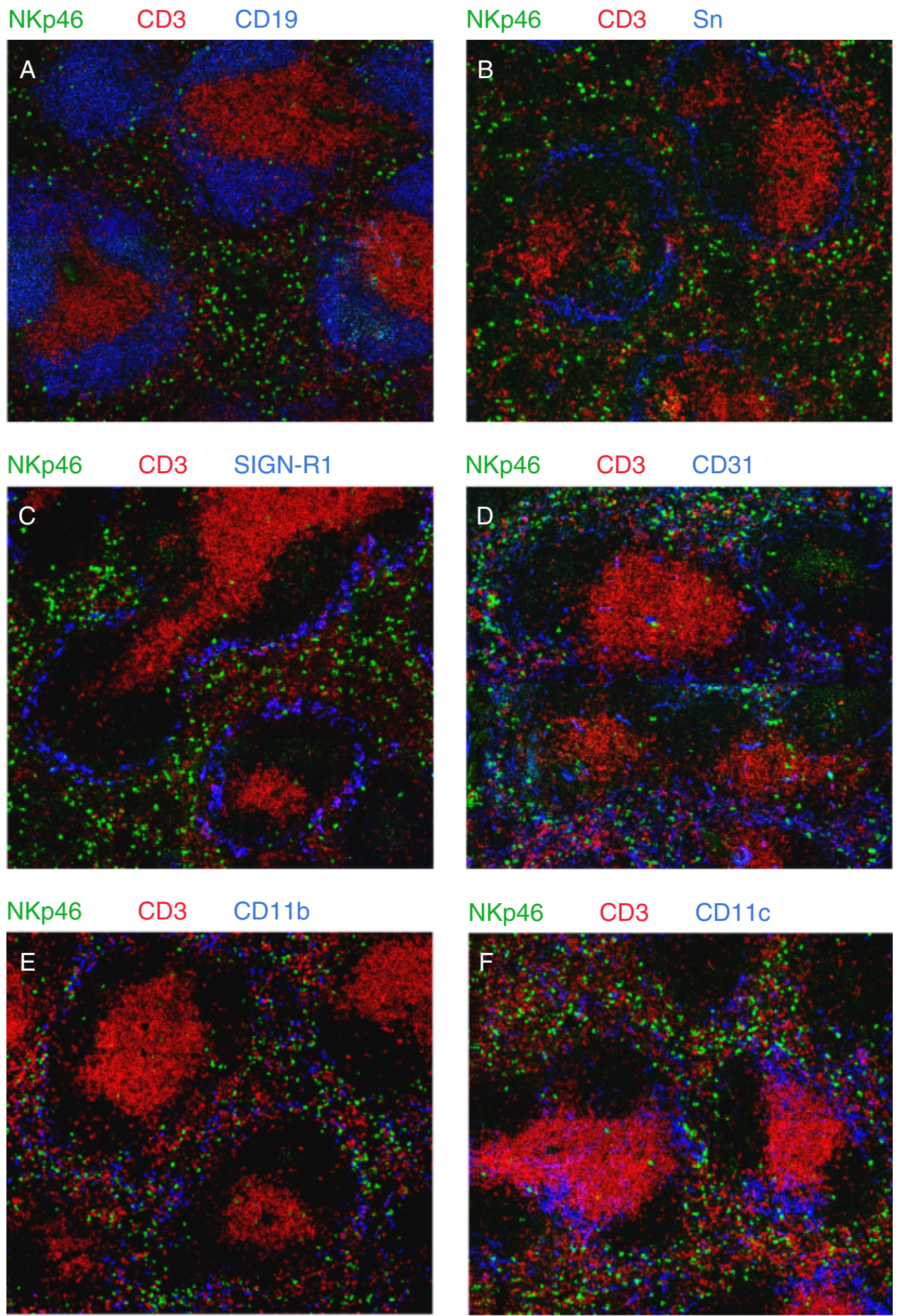

Fig. 2. Localization of natural killer (NK) cells in the spleen. Frozen sections of spleen were fixed with acetone and stained with fluorescently coupled antibodies or biotinylated antibodies revealed with fluorochrome-coupled streptavidin. Anti-CD3 (145-2C11), anti-CD19 (1D3), anti-CD31 (MEC13-3), anti-CD11b (M1/70), and anti-CD11c (HL3) monoclonal antibodies were from BD Pharmingen (San Diego, CA, USA). Anti-sialoadhesin (MOMA-1 for metallophilic macrophages) and anti-Sign-R1 (ER-TR9 for marginal zone macrophages) monoclonal antibodies were obtained from AbD Serotec (Raleigh, NC, USA) and BMA Biomedicals (Augst, Switzerland), respectively. Polyclonal goat anti-NKp46 (R\&D Systems, Minneapolis, MN, USA) was revealed with donkey-anti-goat antibody (Invitrogen, Carlsbad, CA, USA), Sections were visualized by confocal microscopy (Zeiss LSM 510 META, Iena, Germany). Panels A-F show representative images for the indicated staining.

Upon commitment to the NK cell lineage, NK cells go through a complex maturation process that leads to the gradual acquisition of effector functions. Three stages of NK cell maturation can be defined in the mouse based on the expression of $\mathrm{CD} 11 \mathrm{~b}$ and $\mathrm{CD} 27$ : $\mathrm{CD} 27^{\text {high }} \mathrm{CD} 11 \mathrm{~b}$ dull (abbreviated as $\mathrm{CD} 11 \mathrm{~b}^{\text {dull }}$, the most immature), double-positive 
$\mathrm{CD} 11 \mathrm{~b}^{\text {high }} \mathrm{CD} 27^{\text {high }}$ (abbreviated as DP), and $\mathrm{CD} 11 \mathrm{~b}{ }^{\text {high }}$ CD27 ${ }^{\text {dull }}$ (abbreviated as CD27 $7^{\text {dull }}$, the most mature) (43-45). DP and CD $27^{\text {dull }}$ NK cells display stronger effector functions than CD1 $1 b^{\text {dull }}$ NK cells (113). The repartition of the three NK cell subsets varies with the tissue distribution. Whereas CD1 $1 b^{\text {dull }}$ NK cells predominate in BM and LN, DP and especially CD27 $7^{\text {dull }}$ NK cells prevail in the blood, liver, spleen, and lung (44). As discussed later, the expression of different chemotactic receptors participates in the distinct homing capabilities of the NK cell subsets. In human, two subsets of NK cells have been described, CD56 ${ }^{\text {dim }}$ and CD56 ${ }^{\text {bright }}$ NK cells, that share many characteristics with CD $11 b^{\text {dull }}$ and DP/CD2 $7^{\text {dull }}$ NK cells, respectively (45). This resemblance and other observations $(12,46)$ suggest that CD56 ${ }^{\text {bright }}$ could be precursors of $\mathrm{CD} 56^{\mathrm{dim}} \mathrm{NK}$ cells. Like their mouse counterparts, human $\mathrm{CD} 56^{\text {bright }} \mathrm{NK}$ cells are preferentially found in the LN, whereas CD $56^{\text {dim }}$ cells are more abundant in the blood and spleen (12).

It is still unknown how and where NK cells complete their maturation. As the three NK cell subsets are found in all organs, it is likely that NK cell precursors or immature NK cells (CD11 $b^{\text {dull }}$ stage) are seeded from the BM to the periphery, where they further develop in situ under the influence of microenvironmental factors.

\section{NK cell recirculation}

Few data are available on the recirculation of NK cells between organs. Do NK cells traffic through peripheral organs? Do they exit lymphoid and non-lymphoid organs, or do they reside in tissues? An early study (47) showed that upon intravenous transfer into recipient rats, radiolabeled LGLs preferentially homed into the alveolar walls of the lung and the red pulp of the spleen. LGLs were found, however, to be absent from the thoracic duct and LN (47). Later, adoptive transfer experiments in mouse showed that splenic NK cells can home to the spleen, liver, and BM of recipient mice (48-50). To gain an insight into NK cell trafficking, we performed an intravenous adoptive transfer of carboxyfluorescein succinimidyl ester (CFSE)labeled splenocytes into syngeneic, non-irradiated recipient mice. Twenty-four hours post-transfer, the percentage of NK cells within lymphocytes was measured in the blood, spleen, LN, BM, lung, and liver. The results showed that the distribution of transferred NK cells paralleled that of recipient NK cells (Fig. 3 ), as did the distribution of NK1.1 ${ }^{+} \mathrm{T}$ cells. Moreover, the relative proportion of $\mathrm{NK}$ cell subsets $\left(\mathrm{CD} 11 \mathrm{~b}^{\text {dull }}\right.$ to $\left.\mathrm{CD} 27^{\text {dull }}\right)$ was similar between recipient and donor NK cells in every organ (data not shown). This simple experiment shows that (i) splenic NK cells are not programmed to home to the spleen but instead recirculate through all NK cell-containing organs and (ii) NK cell recirculation appears to be subset-specific: LN and $\mathrm{BM}$ are preferentially repopulated by $\mathrm{CD} 11 \mathrm{~b}{ }^{\text {dull }} \mathrm{NK}$ cells and the blood, spleen and lung by CD2 $7^{\text {dull }} \mathrm{NK}$ cells.

The relative contribution of the factors that regulate tissue homing and egress, such as chemotactic receptors or homeostatic mechanisms, in the distribution of NK cells, remains to be addressed. Nevertheless, multiple approaches
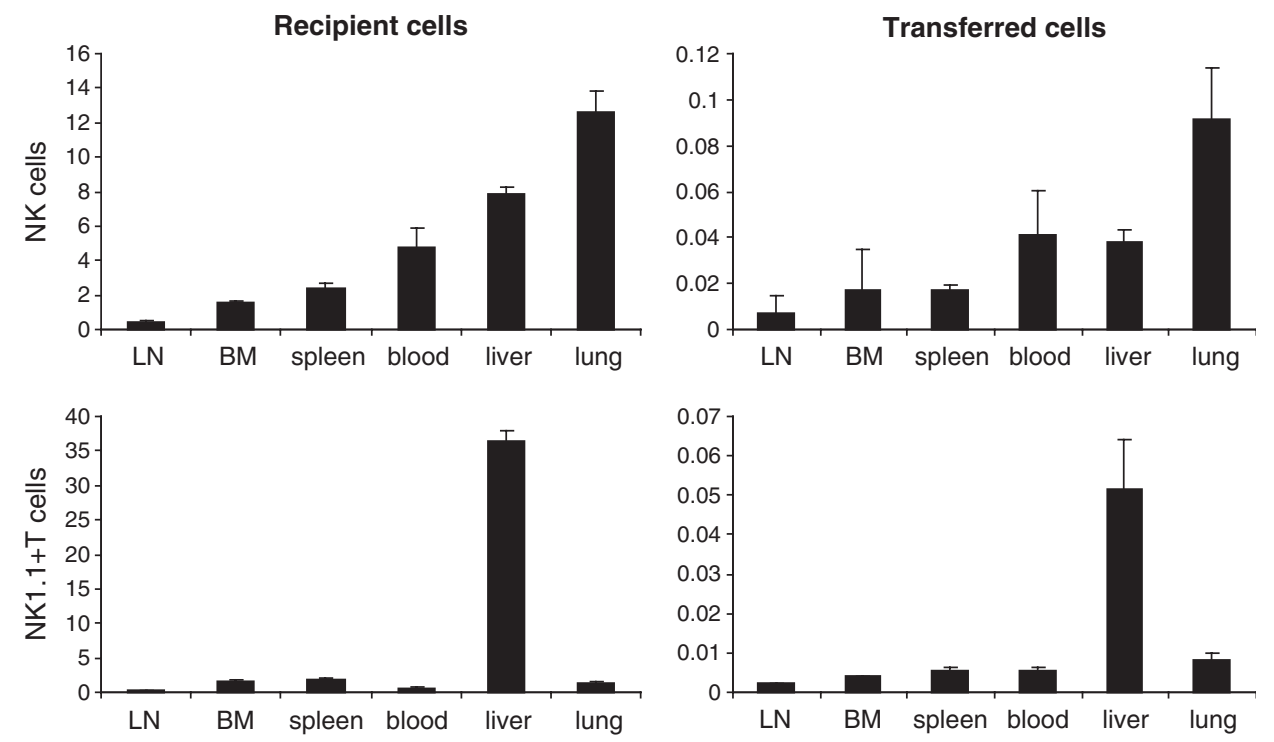

Fig. 3. Recirculation of natural killer (NK) cells. C57BL/ 6 spleen cells were labeled with $3 \mu \mathrm{M} 5$-(and 6-)-carboxyfluorescein succinimidyl ester (CFSE) and injected retro-orbitally to C57BL/ 6 recipient mice. One day after transfer, lymphocyte populations were isolated from the indicated organs. The percentage of NK1.1 ${ }^{+} \mathrm{CD}^{-}$(NK cells) and NK1.1 ${ }^{+} \mathrm{CD}^{+}{ }^{+}$(NK1.1 ${ }^{+} \mathrm{T}^{-}$cells) in gated $\mathrm{CFSE}^{+}$(transferred) and CFSE ${ }^{-}$(recipient) cells was measured by flow cytometry. Results are the mean of six transferred mice in two independent experiments. 


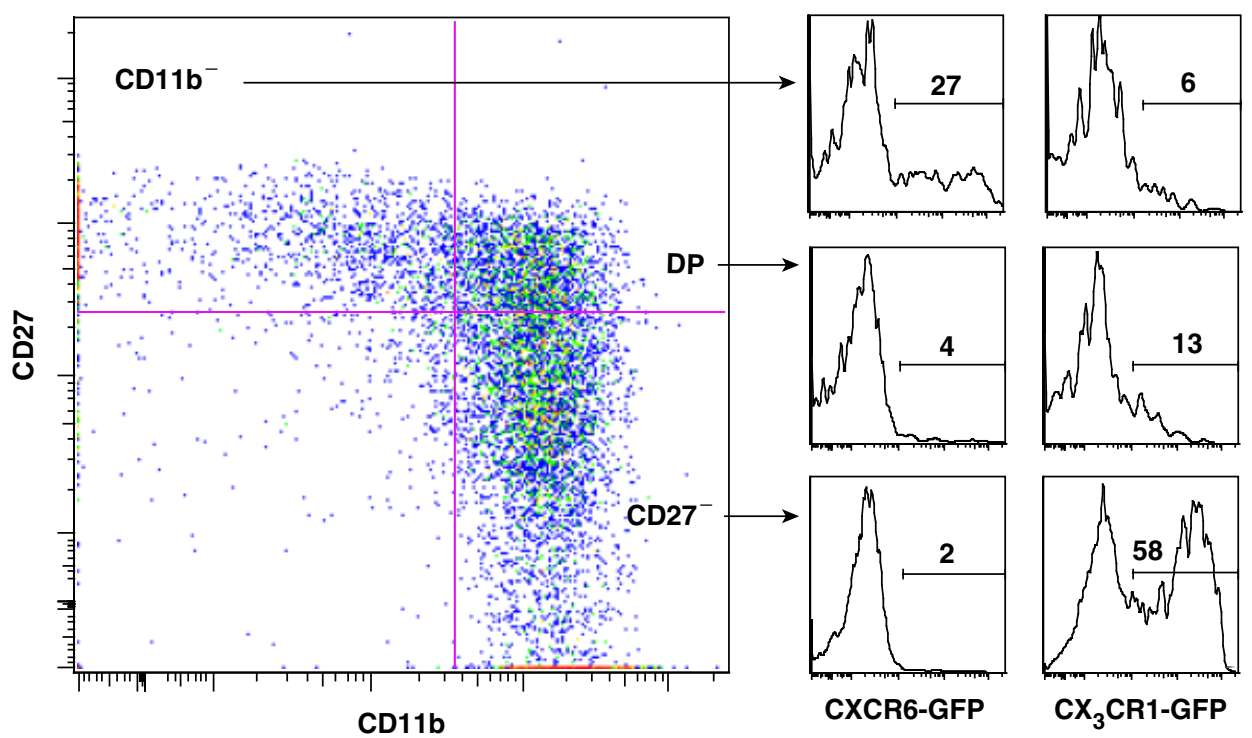

Fig. 4. Expression of CXCR6 and $\mathrm{CX}_{3} \mathrm{CR} 1$ by mouse natural killer (NK) cell subsets. Spleen cells from $\mathrm{CXCR} 6^{\mathrm{gfp} / \mathrm{gfp}_{\mathrm{P}}}$ and $\mathrm{CX}{ }_{3} \mathrm{CR} 1^{\mathrm{gfp} / \mathrm{gfp}_{\mathrm{P}}} \mathrm{knockin}$ mice were stained for CD3, NK1.1, CD11b, and CD27 and analyzed by flow cytometry. Left panel shows the representative expression of CD11b and $\mathrm{CD} 27$ in gated NK1.1 ${ }^{+} \mathrm{CD} 3^{-}$NK cells. NK cell subsets were gated as indicated and CXCR6-GFP or CX $_{3}$ CR1-GFP was measured. Results shown are representative of three mice in each group.

have been used to address the expression of chemotactic receptors in NK cells. First, several studies have measured the expression of chemotactic receptors on NK cells by flow cytometry, when antibodies were available (51-57). Second, several strains of mice were created in which a green fluorescent protein cDNA was knocked in to genes encoding chemokine receptors $(58,59)$. Using such mice, we found that CXCR6 is only expressed by a fraction of CD11 b ${ }^{\text {dull }}$ NK cells, whereas $\mathrm{CX}_{3} \mathrm{CR} 1$ is acquired with maturation, almost selectively expressed by CD27 ${ }^{\text {dull }}$ NK cells (Fig. 4).

Third, microarray experiments have been performed to measure gene expression at the pan-genomic level in human $(60,61)$ and mouse NK cell subsets (Table 1). The findings obtained with these different approaches reveal several trends (Fig. 5).

First, a strong similarity in the expression pattern of chemokine receptors on human and mouse NK cell subsets emphasizes the homology between mouse CD $11 b^{\text {dull }}$ NK cells and $\mathrm{CD} 56^{\text {bright }} \mathrm{NK}$ cells, on the one hand, and mouse DP/ CD27 ${ }^{\text {dull }}$ and human CD56 ${ }^{\text {dim }}$ NK cells on the other. There are, however, important differences. In particular, CCR7 is expressed by human $\mathrm{CD} 56^{\text {bright }} \mathrm{NK}$ cells, but no Ccr7 transcripts are detected in mouse $\mathrm{CD} 11 \mathrm{~b}^{\text {dull }}$ NK cells. This difference might account for the distinct representation of NK cells in LN in humans ( $5 \%$ of lymphocytes) and in mice $(0.5 \%$ of lymphocytes). Second, NK cells are poised to be rapidly recruited on sites of inflammation, as they express receptors for a broad range of inflammatory chemokines (CCR2, CCR5,
Table 1. Relative levels of selectin and integrin transcripts in mouse natural killer (NK) cell subsets

\begin{tabular}{|c|c|c|c|c|}
\hline & other name & $\mathrm{CDIIb}{ }^{-}$ & DP & $\mathrm{CD}^{2} 7^{-}$ \\
\hline \multicolumn{5}{|l|}{ Integrin subunits } \\
\hline |tgal & CD49a & +++ & +++ & +++ \\
\hline Itga2 & CD49b (DX5) & ++ & +++ & +++ \\
\hline Itga3 & CD49c & +++ & +++ & +++ \\
\hline Itga4 & CD49d & ++ & +++ & +++ \\
\hline Itga5 & CD49e & +++ & +++ & +++ \\
\hline Itga6 & CD49f & ++ & ++ & +++ \\
\hline Itga7 & & +++ & +++ & +++ \\
\hline Itgae & CDIO3 & ++ & ++ & +++ \\
\hline Itgal & CDIIa & +++ & +++ & +++ \\
\hline Itgam & CDIIb & + & ++ & +++ \\
\hline Itgav & CD5I & +++ & ++ & ++ \\
\hline Itgax & CDIIC & +++ & +++ & ++ \\
\hline$|\operatorname{tgb}|$ & VLA-4 b & ++ & +++ & +++ \\
\hline $\operatorname{ltgb2}$ & CDI8 & ++ & ++ & +++ \\
\hline Itgb3 & CD6I & +++ & ++ & + \\
\hline Itgb5 & & +++ & +++ & ++ \\
\hline Itgb7 & & ++ & ++ & +++ \\
\hline \multicolumn{5}{|l|}{ Selectins } \\
\hline L-selectin & CD62L & +++ & +++ & +++ \\
\hline P-selectin ligand & PSGLI & +++ & +++ & +++ \\
\hline
\end{tabular}

Spleen cells from C57BL/6 mice were stained for NKI I , CD3, CD27 and CDI I b expression. NK cell subsets were sorted by flow cytometry, and total RNA was extracted using Qiagen RNAmicro kit (Valencia, CA, USA). The quality of total RNA was assessed using an Agilent Bioanalyzer (Santa Clara, CA, USA). Biotinylated antisense cRNA was prepared by using two cycles of in vitro amplification according to the Affymetrix Small Sample Labeling Protocol II (Affymetrix, Santa Clara, CA, USA). Biotinylated cRNA (I $5 \mu \mathrm{g}$ ) was fragmented and hybridized to Affymetrix GeneChip Mouse Genome 4302.0 arrays. All data analyses were performed by using Bioconductor version 1.5 for the statistical software R. Expression values were background corrected, normalized, and summarized by using the default settings of the gcrma package. Accession numbers: The complete microarray data set is available on the CIML website (Vivier lab: http:// www.ciml.univ-mrs.fr/Lab/Vivier/Resource.htm). Changes in the level of expression between subsets are highlighted in bold. 


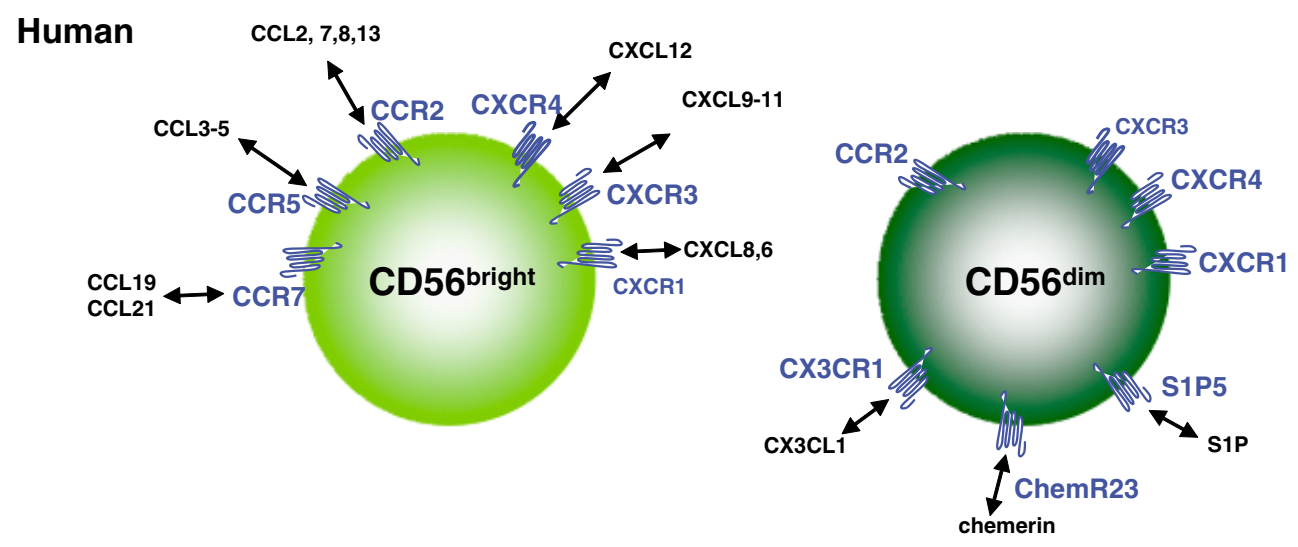

\section{Mouse}
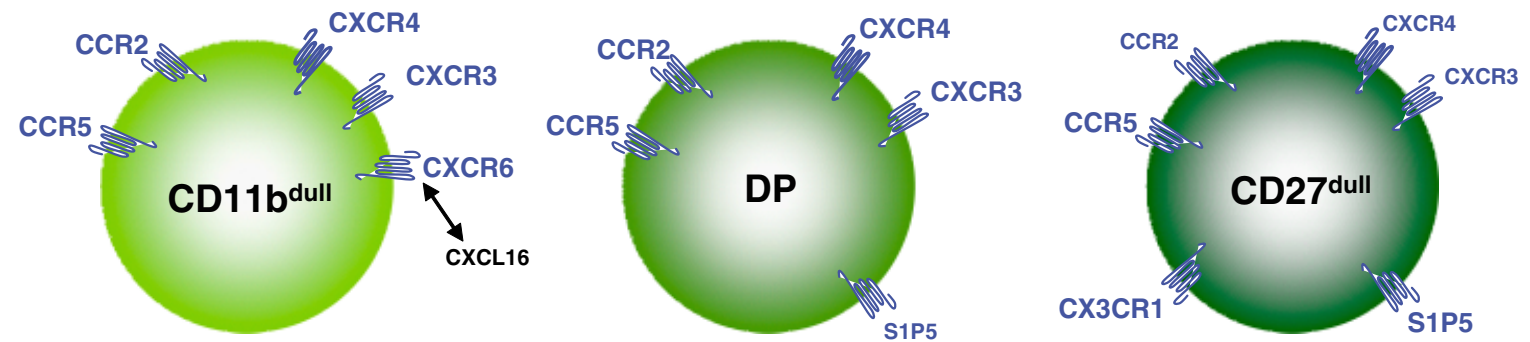

Fig. 5. Expression of chemotactic receptors by natural killer (NK) cells. The pattern of expression of chemotactic receptors displayed by human (top) and mouse (bottom) NK cell subsets is based on the reported expression at the protein level by flow cytometry or at the mRNA level using microarray experiments (see references in text). Chemokine aliases: CCL19: ELC, CCL21: SLC, CCL3: MIP1- $\alpha$, CCL4: MIP1- $\beta$, CCL5: RANTES, CCL2: MCP1, CCL8: MCP2, CCL7: MCP3, CCL13: MCP4, CXCL12: SDF1, CXCL9: MIG, CXCL1 0: IP10, CXCL1 1: I-TAC, CXCL8: IL-8, CXCL6: GCP-2, CX3CL1: fractalkine.

CXCR3, $\left.\mathrm{CX}_{3} \mathrm{CR} 1\right)$. Third, the expression of chemotactic receptors switches over maturation in NK cells. In particular, $\mathrm{CD} 27^{\text {dull }} / \mathrm{CD} 56^{\mathrm{dim}} \mathrm{NK}$ cells lose $\mathrm{CXCR} 3$ (and also CXCR4 in mouse) but acquire $\mathrm{CX}_{3} \mathrm{CR} 1$ (and also ChemR23 in human) expression, an array of receptors that are anticipated to influence their recirculation and their recruitment upon inflammation.

\section{NK cell trafficking at a steady state}

How do NK cells leave the bone marrow?

A role for CXCR4 in human NK cell homing to the BM of reconstituted NOD (nonobese diabetic)/SCID (severe combined immunodeficient) mice was reported (62), suggesting that loss of CXCR4 could contribute to the export of newly produced NK cells. However, CXCR4 seems to be uniformly expressed by NK cells from all organs. Moreover, a recent study showed that mouse treatment with a selective inhibitor of CXCR4 did not induce NK cell mobilization from the BM (63). Another study showed that NK cells were virtually absent from the periphery of CXCR3 knockout mice (64). However, three other studies did not report any defect in the distribution of NK cells in these mice (65-67), questioning the role of CXCR3 in the emigration of NK cells from BM. More recently, we found that NK cell maturation correlated with the acquisition of $\mathrm{S}_{1} \mathrm{P}_{5}$, one of the five sphingosine-phosphate (S1P) G-protein-coupled receptors (113). S1P is a secreted lysophospholipid bound extensively to albumin and other plasma proteins. Coordinated activities of biosynthetic (sphingosine kinases) and biodegradative (sphingosine lyase and phosphatases) enzymes maintain S1P gradients in vivo, with high S1P concentrations in extracellular fluids and low S1P concentrations in tissues $(68,69)$. In S1 $p_{5}$-deficient mice, a drastic decrease in peripheral NK cell counts is observed in the blood, spleen, and lung. This defective homing is NK cellintrinsic and correlates with an increased number of NK cells in the $\mathrm{BM}$ and $\mathrm{LN}$. $\mathrm{S}_{1} \mathrm{P}_{5}$ operates in NK cells as a chemotactic receptor for $\mathrm{S} 1 \mathrm{P}$ in vitro, promoting $\mathrm{NK}$ cell homing in the blood, spleen, and lung in vivo. The extent of NK cell accumulation in BM and LN correlates with the level of $\mathrm{S}_{1} \mathrm{P}_{5}$ expression (113). Altogether, these observations suggest that $\mathrm{S} \mathrm{P}_{5}$ provides an egress signal to NK cells, allowing both their export from the BM and their exit from LN (Fig. 6). Interestingly, $\mathrm{Id}^{-/-}{\mathrm{E} 2 \mathrm{a}^{-/-}}^{-1}$ mice have normal BM NK cells but very few mature NK cells in the spleen (70), prompting an investigation 


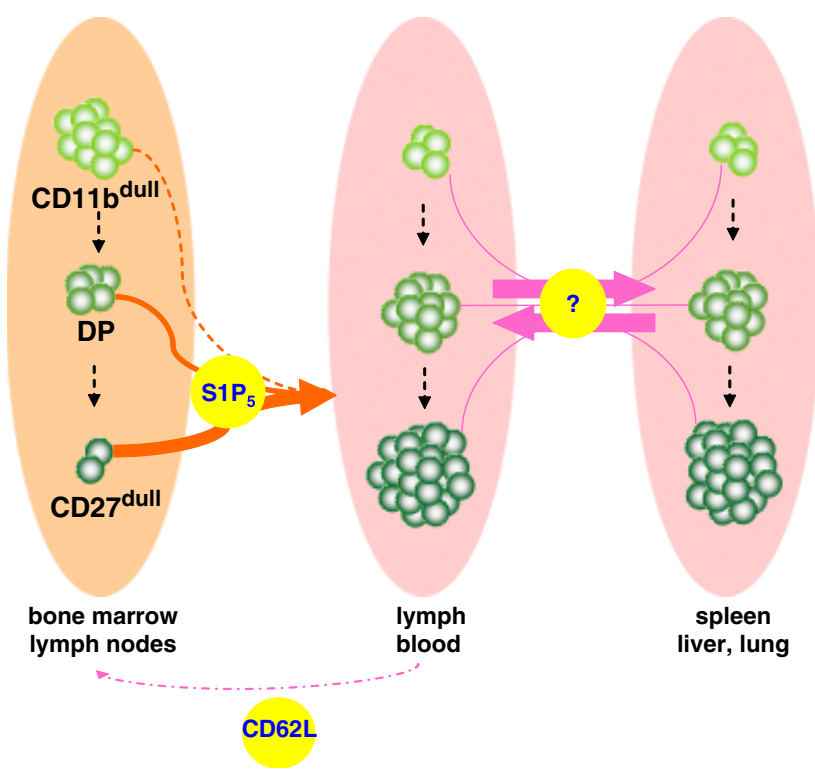

Fig. 6. Model of mouse natural killer (NK) cell circulation at steady state. NK cells develop mostly in the bone marrow (BM) and, for the $\mathrm{CD} 127^{+}$fraction, also in lymph node (LN) and thymus. NK cells mature from the $\mathrm{CD} 11 \mathrm{~b}^{\text {dull }}$ stage to the double positive $\mathrm{CD} 11 \mathrm{~b}{ }^{\text {high }} \mathrm{CD} 27^{\text {high }}$ (DP) and further to the $\mathrm{CD} 27^{\text {dull }}$ stage in all organs, starting in the BM (vertical dotted arrows). Upon maturation, they acquire $\mathrm{S}_{1} \mathrm{P}_{5}$ expression and exit the $\mathrm{BM}$ in a $\mathrm{S} \mathrm{P}_{5}$-dependent manner. In this model, the more NK cells express $\mathrm{S}_{1} \mathrm{P}_{5}$, the more they exit the $\mathrm{BM}$. Once in the periphery, they may return to $\mathrm{BM}$ and LN, through a CD62L-dependent mechanism for the LN.

of whether these transcription factors control $\mathrm{S} \mathrm{P}_{5}$ expression and/or function.

\section{How do NK cells reach lymphoid organs?}

Like other lymphocytes, NK cells enter LNs through high endothelial venules (HEVs) and the spleen through the marginal sinus. CD56 $6^{\text {bright }}$ human NK cells express L-selectin (CD62L) that allows interaction with glycosylated L-selectin ligands on HEVs (71). CD62L is expressed at a similar level on mouse NK cell subsets isolated from the LN (44) and is required for mouse NK cell entry in LNs (72) (Fig. 6). Whether CD62L is sufficient for the entry is not known. As discussed previously, most mouse NK cells localize in the sinusoids around $\mathrm{T}$ and $\mathrm{B}$-cell areas, a location reminiscent of that in spleen where NK cells are found in the red pulp surrounding the white pulp. One possibility is that this area is reached by default, in the absence of CCR7 expression. Consistent with this model, human LN CD56 bright NK cells that do express CCR7 are localized, at least in part, in the T-cell cortex (73). Recently, it was shown that CCR7 is induced on CD56 ${ }^{\text {dim }}$ cells by IL-18 in vitro (74), suggesting that under certain conditions, these cells could also traffic to LN.
Transfer experiments have shown that peripheral NK cells may also return to the BM. Central memory $\mathrm{T}$ cells preferentially home in this tissue by a mechanism that depends both on CXCL12 (CXCR4 ligand) and on E/P/L selectins (75). Whether this is also the case for NK cells requires further investigation.

\section{How do NK cells reach non-lymphoid organs?}

The distribution of NK cell subsets in the blood, spleen, liver, and lung is very similar, with a majority of $\mathrm{CD} 27^{\text {dull }} \mathrm{NK}$ cells. $\mathrm{S} 1 \mathrm{P}_{5}$ deficiency affects NK cells from these compartments in the same way (113). This finding suggests, after their

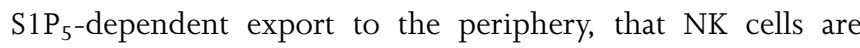
carried by the blood flow in a $\mathrm{S}_{1} \mathrm{P}_{5}$-independent manner (Fig. 6). A fraction of $\mathrm{CD} 11 \mathrm{~b}{ }^{\text {dull }}$ NK cells expressing CXCR6 is enriched in the liver. Similar to what was shown for NKT cells, these CXCR6 NK cells could patrol hepatic sinusoids through the interaction of CXCR6 with endothelium-bound CXCL16 (58).

\section{NK cell trafficking under inflammatory conditions}

Upon inflammation, NK mouse cells may be recruited in various organs such as the LN, lung, liver, or central nervous system (CNS), and can then extravasate in the parenchyma or cavities (6). The migration of leukocytes from the vascular lumen to tissues depends on a series of sequential molecular interactions between leukocytes and endothelial cells, involving selectins, integrins, and chemokine receptors.

\section{Selectins}

In the mouse, L-selectin and P-selectin glycoprotein ligand-1 (PSGL-1) are expressed at similar levels on NK cell subsets (Table 1). L-selectin is required for mouse NK cell homing and recruitment to the LN (72). In human, CD56 $6^{\text {bright }}$ but not mature $\mathrm{CD} 56{ }^{\mathrm{dim}} \mathrm{CD} 16^{+}$NK cells also express L-selectin (71, 76). Sialyl stage-specific embryonic antigen 1 and an uncharacterized sLe ${ }^{\mathrm{x}}$-bearing receptor may serve as E-selectin ligands $(77,78)$. Although PSGL-1 is expressed on freshly isolated human NK cells, only a minor population of NK cells binds P-selectin-immunoglobulin (Ig) $(78,79)$. Human NK cell differentiation is accompanied by the cell surface expression of a mucin-like glycoprotein bearing an NK cellrestricted keratan sulfate-related lactosamine, the PEN5 epitope (80). The PEN5 carbohydrate decorates PSGL-1, creating a unique binding site for L-selectin, which is independent of PSGL-1 tyrosine sulfation (76). By analogy to the ability of rolling neutrophils to capture free-flowing neutrophils in a PSGL-1:L-selectin-dependent manner (81), the PEN5 epitope 
Table 2. Experimental models of natural killer (NK) cell trafficking

\begin{tabular}{|c|c|c|c|}
\hline Stimulus & $\begin{array}{l}\text { Organ where NK cells } \\
\text { are recruited }\end{array}$ & Mechanisms & Reference \\
\hline \multicolumn{4}{|l|}{ Human } \\
\hline Granulomas in TAP2-deficient patients & Skin lung & CCR2? & Hanna et al. (93) \\
\hline Oral lichen planus & Oral mucosa & ChemR23 & Parolini et al. (57) \\
\hline Hemolytic uremic syndrome & Kidney & CX3CRI & Ramos et al. (95) \\
\hline Psoriasis & Skin & CXCR3/CCR5 & Ottaviani et al. (20) \\
\hline Menstruation & Uterus & CXCR3? & Sentman et al. (96) \\
\hline Invasive trophoblasts & Decidua & CXCLI $2 / C X C R 4$ & Hanna et al. (94) \\
\hline $\mathrm{IL}-18$ & LN? & CCR7 & Mailliard et al. (74) \\
\hline \multicolumn{4}{|l|}{ Mouse } \\
\hline TLR7/8 ligands, injection sc & Draining LN & CXCR3 & Martin-Fontecha et al. (87) \\
\hline ConA-induced hepatitis & $\begin{array}{l}\text { Blood, mobilization } \\
\text { from spleen }\end{array}$ & CXCR3 & Wald et al. (65) \\
\hline ConA-induced hepatitis & Liver & CCRI & Wald et al. (9l) \\
\hline MCMV, i.p. & Liver & MCPI/CCR2 & Hokeness et al. (83) \\
\hline MCMV or poly(l:C), i.p. & Liver & MIPI-a/CCR5? & Salazar Mather et al. (89) \\
\hline Toxoplasma gondii & Liver, spleen & CCR5 & Khan et al. (85) \\
\hline Dengue virus & Liver & CXCLIO/CXCR3? & Chen et al. (82) \\
\hline Bordetella bronchiseptica & Lung & CXCR3 & Widney et al. (66) \\
\hline Bleomycin-induced lung fibrosis & Lung & CXCR3 & Jiang et al. (64) \\
\hline Intracerebral coronavirus infection & CNS & CXCLIO/CXCR3? & Stiles et al. (90) \\
\hline MOG (s.c.)-induced EAE & CNS & CX3CRI not CXCR3 & Huang et al., Liu et al. $(84,67)$ \\
\hline None & Lung & CX3CRI & Yu et al. (92) \\
\hline $\mathrm{B}|6-\mathrm{F}| 0$ & Lung & CX3CRI & Yu et al. (92) \\
\hline Invasive aspergillosis & Lung & MCPI/CCR2 & Morrison et al. (88) \\
\hline EL4 tumor cells, s.c. & Tumor site & CX3CRI & Lavergne et al. (86) \\
\hline HSV2 genital infection & CNS & CCR5 & Thapa et al. (25) \\
\hline
\end{tabular}

Compilation of data from the literature describing the recruitment of NK cells in various organs in response to the indicated stimuli. In each case, the receptor involved is indicated in bold.

HSV, herpes simplex virus; CNS, central nervous system; MCMV, mouse cytomegalovirus; LN, lymph node.

might allow NK cells to interact with other L-selectin ${ }^{+}$ leukocytes (e.g. neutrophils, monocytes, or T/B lymphocytes) attached to the inflammatory endothelium to amplify the immune response.

\section{Chemotaxis}

The role of chemokine receptors in mouse NK cell recruitment to inflammatory sites has been studied using knockout strains and blocking antibodies $(25,64-67,82-92)$. In humans, the expression of chemokines and their receptors at inflammatory sites has also provided some information (20, 57, 74, 93-96) (Table 2)

Four receptors appear to play a key role in mouse NK cell recruitment following an inflammatory stimulus: CCR2, CCR5, CXCR3, and $\mathrm{CX}_{3} \mathrm{CR} 1$. These receptors allow $\mathrm{NK}$ cells to respond to a large array of inflammatory chemokines such as CCL2, CCL3, CCL5, CCL7, CCL8, CCL9, CCL11, CCL13, CXCL9-11 and CX3CL1. This broad responsiveness could warrant NK cell recruitment in situations where limited sets of chemokines are expressed. Thus, NK cell recruitment in the same tissue can be mediated by different chemokine receptors. For example, human NK cell recruitment to the epithelia appears to be dependent on CCR2, CCR5, CXCR3, or
ChemR23, depending on the inflammatory conditions (20, 57 , 93). Not only may NK cells respond to different chemokines, but it also seems that chemokines may act in concert to recruit them. CCR 2 and CCR 5 are both required for NK cell recruitment to the liver of mouse cytomegalovirus (MCMV)-infected mice $(83,89)$. A similar phenomenon had been observed previously for monocytes (97). Importantly, NK cell subsets could also be differentially recruited, depending on the stimulus. Indeed, $\mathrm{CX}_{3} \mathrm{CR} 1$ but not $\mathrm{CXCR} 3$ is required for NK cell recruitment in the CNS in a model of experimental autoimmune encephalomyelitis $(67,84)$. Conversely, CXCR3 has a central role in NK cell recruitment to the inflammatory $\mathrm{LN}$ (87). As CXCR3 and $\mathrm{CX}_{3} \mathrm{CR} 1$ are expressed in a quasimutually exclusive fashion on NK cell subsets (Fig. 5), this finding suggests that different NK cell subsets may be independently recruited in distinct inflammatory settings. Such a division of labor has already been shown for other types of leukocytes, including monocytes (98) and memory $\mathrm{CD}^{+} \mathrm{T}$ cells (99). Besides chemokines, NK cells have been shown to respond to various other chemotactic compounds that are either induced or augmented upon inflammation. These include lysophosphatidic acid (100), N-formyl-methionylleucyl-phenylalanine (f-MLP) (101), leukotrienes (102), and 

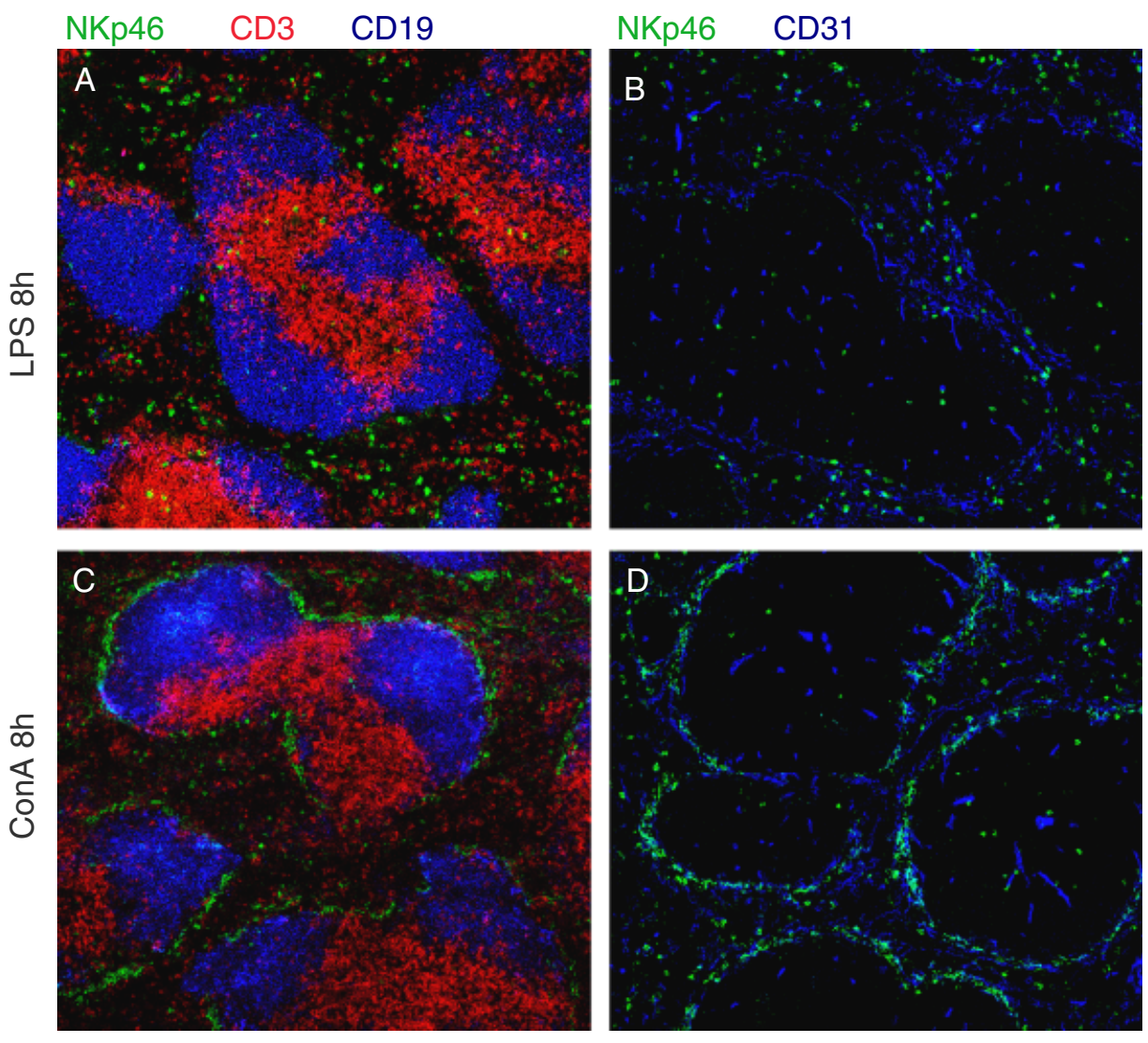

Fig. 7. Relocalization of natural killer (NK) cells in the spleen in response to Con-A injection. C57BL/ 6 mice were treated with indicated stimuli [Con-A, Sigma (St. Louis, MO, USA): $300 \mu$ i.v., lipopolysaccharide (LPS), Sigma (St. Louis, MO, USA), $25 \mu$ g i.v.] for the indicated times. Frozen sections of spleen were fixed with acetone and stained with anti-CD3, anti-CD19, (panel A, C) or anti-CD31 and goat anti-NKp46 antibodies (panel B, D), and goat anti-NKp46 antibodies, as described in Fig. 2. Sections were visualized by confocal microscopy.

C5a (103). The roles of these inflammatory mediators and of their receptors in NK cell recruitment in vivo remain to be thoroughly investigated.

\section{Integrins}

Upon activation by chemokines, NK cells interact firmly with the endothelium through integrins. The role of LFA1 (leukocyte function-associated antigen-1), as for other leukocytes, has been shown to be central in NK cell extravasation (104). Interestingly, NK cells sequentially express different integrins over development and maturation (43). To gain an insight into this phenomenon, we examined integrin expression at the mRNA level in sorted NK cells subsets, using microarrays. All NK cells express many transcripts of integrins involved in extravasation (Table 1). As reported previously, we found that $\mathrm{CD} 49 \mathrm{~b}$ and $\mathrm{CD} 11 \mathrm{~b}$ were acquired while CD51 was decreased upon NK cell maturation. Our data also show that CD11c and especially CD61 ( $\beta 3$ integrin) are decreased upon maturation. The significance of this observation is unclear, but different sets of integrins may contribute to the differential recruitment of NK cell subsets upon inflammation. Besides integrins, NK cell adhesion to the endothelium could also be mediated by $\mathrm{CX}_{3} \mathrm{CR} 1$. Indeed, it was reported previously that $\mathrm{CX}_{3} \mathrm{CL} 1$ mediates the rapid capture, integrin-independent firm adhesion, and activation of circulating leukocytes under flowthrough $\mathrm{CX}_{3} \mathrm{CR} 1$ (105).

\section{Recruitment of NK cells to the inflammatory liver}

NK cells migrate to the liver in response to a variety of stimuli, such as injection of maleic anhydride divinyl ether (MVE-2), Corynebacterium parvum (106), poly(I:C) $(89,107,108)$, MCMV (109), hepatitis B (110), or concanavalin-A (Con-A) (111). Concomitant to the increase in liver NK cells, NK cell counts decrease in the spleen and BM, suggesting that these organs serve as reservoirs of NK cells in case of inflammation (65). Various chemokine receptors may orchestrate this recruitment. CXCR3 is partly required in the mobilization of spleen NK cells, while CCR 1 is required for the accumulation of NK cells in the liver (65). To gain an insight into the mechanism of spleen NK cell mobilization, we performed immunofluorescence experiments on frozen sections of spleens obtained from mice intravenously injected with lipopoly- 

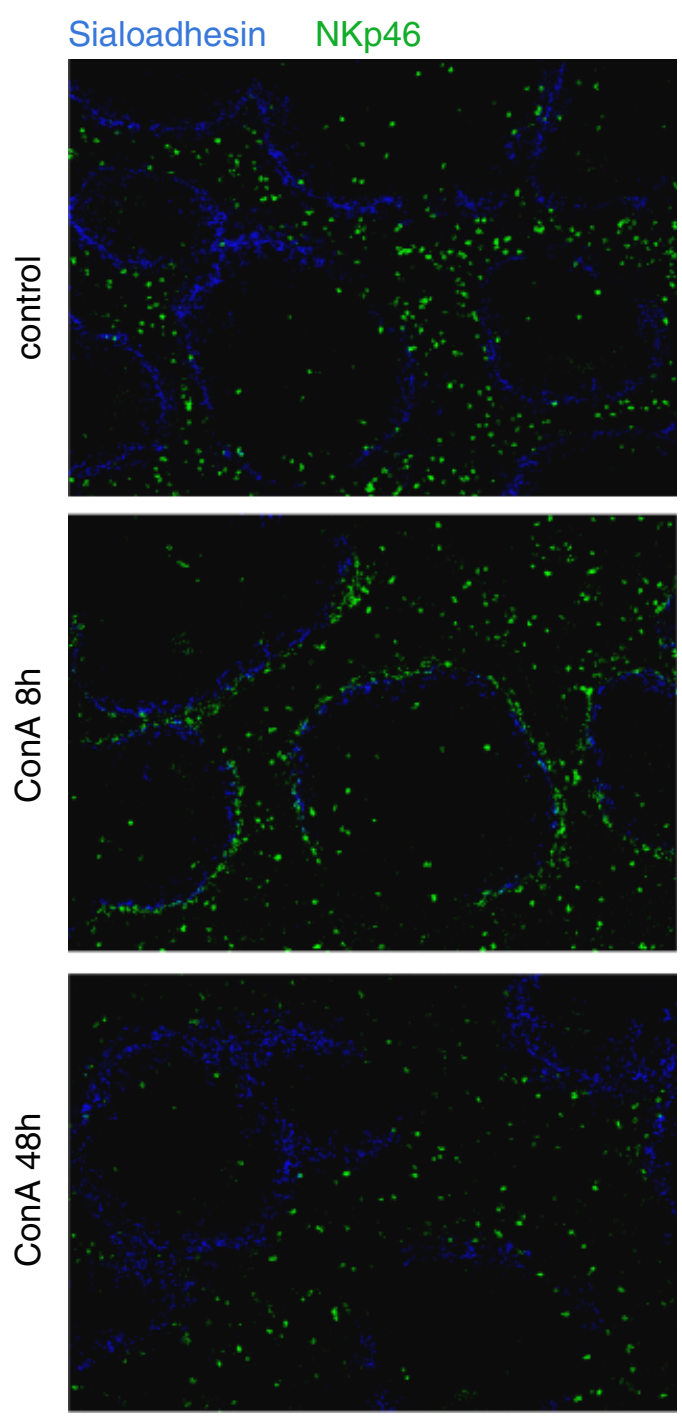

Fig. 8. Kinetics of natural killer (NK) cell response to Con-A injection. C57BL/ 6 mice were treated with Con-A $(300 \mu \mathrm{g})$ and sacrificed at the indicated times. Frozen sections of spleen were fixed with acetone and stained with anti-sialoadhesin and goat anti-NKp46 antibodies, as described in Fig. 2. Sections were visualized by confocal microscopy.

saccharide (LPS) or Con-A. A redistribution of splenic NK cells was observed in response to Con-A injection (Fig. 7).

NK cells appear to migrate from the red pulp to the marginal zone. This relocalization of NK cells was not observed when mice were treated with LPS, although this stimulus induces a massive redistribution of dendritic cells (Fig. $7 \mathrm{~A}$ and data not shown). After Con-A injection, NK cells are thus found in close contact with marginal zone macrophages (Fig. 8). It will be of interest to test whether CXCR3 is involved in this process. This phenomenon is transient, as $48 \mathrm{~h}$ after Con-A injection, NK cell distribution in the spleen is normal (Fig. 8).

\section{Recruitment of NK cells to the inflammatory LN}

A massive recruitment of NK cells is observed in the draining LN in response to a footpad injection of Leishmania major (29), TLR 7/8 ligands, or LPS-activated dendritic cells (87). This recruitment is dependent on CXCR3 (87). CXCR3 ligands such as CXCL9 are expressed on the surface of inflammatory HEVs (112). Under inflammatory conditions, most NK cells are recruited preferentially to the T-cell zone of the LN, near HEVs, in close proximity to dendritic cells (29). NK cell recruitment is required for T-helper 1 cell polarization of naive $\mathrm{T}$ cells activated within the LN (87). In another system, it was found that CD62L was also required for the recruitment on the inflammatory LN in response to a subcutaneous injection of tumor cells (72).

\section{Concluding remarks}

The precise knowledge of the anatomy of the immune system is obviously critical for our understanding of immunity. In contrast to $\mathrm{T}, \mathrm{B}$, and dendritic cells, the trafficking of NK cells in normal and disease conditions is poorly characterized. Nevertheless, it appears that NK cells patrol lymphoid and non-lymphoid organs. At a steady state, NK cells are present at a high frequency in the circulation, ready to extravasate to tissues under inflammatory conditions. Besides the roles of $\mathrm{S} \mathrm{P}_{5}$ and chemokine receptors, the set of molecules that govern NK cells trafficking in vivo remain to be identified. The dissection of the mechanisms that regulate NK cell migration may likely provide new perspectives for the manipulation of these cells for therapeutic purposes, as exemplified by the use of the S1P agonist, FTY720, as a T- and B-cell immunosuppressant.

\section{References}

1. Moretta A, Bottino C, Mingari MC, Biassoni R, Moretta L. What is a natural killer cell? Nat Immunol 2002;3: 6-8.

2. Raulet DH. Interplay of natural killer cells and their receptors with the adaptive immune response. Nat Immunol 2004;5:996-1002.
3. Cerwenka A, Lanier LL. Ligands for natural killer cell receptors: redundancy or specificity. Immunol Rev 2001;181:158-169.

4. Vilches C, Parham P. KIR: diverse, rapidly evolving receptors of innate and adaptive immunity. Annu Rev Immunol 2002;20:217-251.
5. Vivier E, Nunès JA, Vély F. Natural killer cell signaling pathways. Science 2004;306: 1517-1519.

6. Trinchieri G. Biology of natural killer cells. Adv Immunol 1989;47:187-376.

7. Reynolds CW, Timonen T, Herberman RB. Natural killer (NK) cell activity in the rat. I. Isolation and characterization of the 
effector cells. J Immunol 1981;127: 282-287.

8. Colucci F, Caligiuri MA, Di Santo JP. What does it take to make a natural killer? Nat Rev Immunol 2003;3:413-425.

9. Masopust D, Vezys V, Marzo AL, Lefrancois L. Preferential localization of effector memory cells in nonlymphoid tissue. Science 2001;291:2413-2417.

10. Crispe IN, Mehal WZ. Strange brew: T cells in the liver. Immunol Today 1996; 17:522-525.

11. Norris $\mathrm{S}$, et al. Resident human hepatic lymphocytes are phenotypically different from circulating lymphocytes. J Hepatol 1998;28:84-90.

12. Ferlazzo G, et al. The abundant NK cells in human secondary lymphoid tissues require activation to express killer cell Ig-like receptors and become cytolytic. J Immunol 2004;172:1455-1462.

13. Moffett-King A. Natural killer cells and pregnancy. Nat Rev Immunol 2002; 2:656-663.

14. Ebert LM, Meuter S, Moser B. Homing and function of human skin $\{$ gamma $\}$ delta $\}$ $\mathrm{T}$ cells and NK cells: relevance for tumor surveillance. J Immunol 2006;176: 4331-4336.

15. Hunger RE, Yawalkar N, Braathen LR, Brand CU. The HECA-452 epitope is highly expressed on lymph cells derived from human skin. Br J Dermatol 1999;141: 565-569.

16. Buentke E, et al. Natural killer and dendritic cell contact in lesional atopic dermatitis skin - Malassezia-influenced cell interaction. J Invest Dermatol 2002;119: 850-857.

17. O'Leary JG, Goodarzi M, Drayton DL, von Andrian UH. T cell- and B cell-independent adaptive immunity mediated by natural killer cells. Nat Immunol 2006;7: 507-516.

18. Cameron AL, Kirby B, Fei W, Griffiths CE. Natural killer and natural killer-T cells in psoriasis. Arch Dermatol Res 2002;294: 363-369.

19. Gilhar A, et al. Psoriasis is mediated by a cutaneous defect triggered by activated immunocytes: induction of psoriasis by cells with natural killer receptors. J Invest Dermatol 2002;119:384-391.

20. Ottaviani C, Nasorri F, Bedini C, de Pita O, Girolomoni G, Cavani A.

CD56brightCD16( - ) NK cells accumulate in psoriatic skin in response to CXCL10 and CCL5 and exacerbate skin inflammation. Eur J Immunol 2006;36:118-128.

21. Eiras $P$, et al. Intestinal intraepithelial lymphocytes contain a $\mathrm{CD} 3-\mathrm{CD} 7+$ subset expressing natural killer markers and a singular pattern of adhesion molecules. Scand J Immunol 2000;

52:1-6.

22. Leon F, Roldan E, Sanchez L, Camarero C, Bootello A, Roy G. Human small-intestinal epithelium contains functional natural killer lymphocytes. Gastroenterology 2003;125: 345-356.

23. Tagliabue A, Befus AD, Clark DA, Bienenstock J. Characteristics of natural killer cells in the murine intestinal epithelium and lamina propria. J Exp Med 1982;155:1785-1796.

24. Tagliabue A, Luini W, Soldateschi D, Boraschi D. Natural killer activity of gut mucosal lymphoid cells in mice. Eur J Immunol 1981;11:919-922.

25. Thapa M, Kuziel WA, Carr DJ. Susceptibility of CCR5-deficient mice to genital herpes simplex virus type 2 is linked to NK cell mobilization. J Virol 2007;81: 3704-3713.

26. Ashkar AA, Rosenthal KL. Interleukin-15 and Natural Killer and NKT Cells Play a Critical Role in Innate Protection against Genital Herpes Simplex Virus Type 2 Infection. J Virol 2003;77: 10168-10171.

27. Gill N, Rosenthal KL, Ashkar AA. NK and NKT cell-independent contribution of interleukin-15 to innate protection against mucosal viral infection. J Virol 2005;79:4470-4478.

28. Andrews DW, Farrell HE, Densley EH, Scalzo AA, Shellam GR, Degli-Esposti MA. NK1.1 + cells and murine cytomegalovirus infection: what happens in situ? J Immunol 2001;166:1796-1802.

29. Bajenoff M, et al. Natural killer cell behavior in lymph nodes revealed by static and realtime imaging. J Exp Med 2006;203: 619-631.

30. Dokun AO, Chu DT, Yang L, Bendelac AS, Yokoyama WM. Analysis of in situ NK cell responses during viral infection. J Immunol 2001;167:5286-5293.

31. Grundy MA, Sentman CL. Immunodeficient mice have elevated numbers of NK cells in non-lymphoid tissues. Exp Cell Res 2006; 312:3920-3926.

32. Salazar-Mather TP, Ishikawa R, Biron CA. NK cell trafficking and cytokine expression in splenic compartments after IFN induction and viral infection. J Immunol 1996;157: 3054-3064.

33. Walzer $\mathrm{T}$, et al. Identification, activation, and selective in vivo ablation of mouse NK cells via NKp46. Proc Natl Acad Sci USA 2007; 104:3384-3389.

34. Moretta A. Natural killer cells and dendritic cells: rendezvous in abused tissues. Nat Rev Immunol 2002;2:957-964.

35. Walzer T, Dalod M, Robbins SH, Zitvogel L, Vivier E. Natural-killer cells and dendritic cells: "l'union fait la force". Blood 2005; 106:2252-2258.

36. Degli-Esposti MA, Smyth MJ. Close encounters of different kinds: dendritic cells and NK cells take centre stage. Nat Rev Immunol 2005;5:112-124.

37. Newman KC, Riley EM. Whatever turns you on: accessory-cell-dependent activation of NK cells by pathogens. Nat Rev Immunol 2007; 7:279-291.

38. Racanelli V, Rehermann B. The liver as an immunological organ. Hepatology 2006; 43:S54-S62.

39. Freud AG, et al. A human CD34(+) subset resides in lymph nodes and differentiates into CD56bright natural killer cells. Immunity 2005;22:295-304.

40. Vosshenrich CA, et al. A thymic pathway of mouse natural killer cell development characterized by expression of GATA-3 and CD127. Nat Immunol 2006;7:1217-1224.

41. Stewart CA, Walzer T, Robbins SH, Malissen B, Vivier E, Prinz I. Germ-line and rearranged Tcrd transcription distinguish bona fide NK cells and NK-like gammadelta T cells. Eur J Immunol 2007;37: 1442-1452.

42. Takeda K, et al. TRAIL identifies immature natural killer cells in newborn mice and adult mouse liver. Blood 2005;105: 2082-2089.

43. Kim S, et al. In vivo developmental stages in murine natural killer cell maturation. Nat Immunol 2002;3:523-528.

44. Hayakawa Y, Smyth MJ. CD27 dissects mature NK cells into two subsets with distinct responsiveness and migratory capacity. J Immunol 2006;1 176: 1517-1524.

45. Hayakawa Y, Huntington ND, Nutt SL, Smyth MJ. Functional subsets of mouse natural killer cells. Immunol Rev 2006; 214:47-55.

46. Romagnani C, et al. CD56brightCD16- killer Ig-like receptor- NK cells display longer telomeres and acquire features of CD56 dim NK cells upon activation. J Immunol 2007; 178:4947-4955.

47. Rolstad B, Herberman RB, Reynolds CW. Natural killer cell activity in the rat. V. The circulation patterns and tissue localization of peripheral blood large granular lymphocytes (LGL). J Immunol 1986;136:2800-2808.

48. Cooper MA, et al. In vivo evidence for a dependence on interleukin 15 for survival of natural killer cells. Blood 2002;100: 3633-3638.

49. Prlic M, Blazar BR, Farrar MA, Jameson SC. In vivo survival and homeostatic proliferation of natural killer cells. J Exp Med 2003;197:967-976.

50. Ranson T, Vosshenrich CA, Corcuff E, Richard O, Muller W, Di Santo JP. IL-15 is an 
essential mediator of peripheral

NK-cell homeostasis. Blood 2003;101:

4887-4893.

51. Campbell Jj, et al. Unique subpopulations of CD56+ NK and NK-T peripheral blood lymphocytes identified by chemokine receptor expression repertoire. J Immunol 2001;166:6477-6482.

52. Imai $\mathrm{T}$, et al. Identification and molecular characterization of fractalkine receptor CX3CR1, which mediates both leukocyte migration and adhesion. Cell 1997;91: 521-530.

53. Inngjerdingen M, Damaj B, Maghazachi AA. Human NK cells express CC chemokine receptors 4 and 8 and respond to thymus and activation-regulated chemokine, macrophage-derived chemokine, and I-309. J Immunol 2000;164:4048-4054.

54. Inngjerdingen M, Damaj B, Maghazachi AA. Expression and regulation of chemokine receptors in human natural killer cells. Blood 2001;97:367-375.

55. Johnston B, Kim CH, Soler D, Emoto M, Butcher EC. Differential chemokine responses and homing patterns of murine TCR alpha beta NKT cell subsets. J Immunol 2003;171:2960-2969.

56. Nishimura M, et al. Dual functions of fractalkine/CX3C ligand 1 in trafficking of perforin + /granzyme B + cytotoxic effector lymphocytes that are defined by CX3CR 1 expression. J Immunol 2002;168 6173-6180

57. Parolini S, et al. The role of chemerin in the colocalization of NK and dendritic cell subsets into inflamed tissues. Blood 2007; 109:3625-3632.

58. Geissmann F, et al. Intravascular immune surveillance by CXCR6 + NKT cells patrolling liver sinusoids. PLoS Biol 2005:3:e113.

59. Jung $\mathrm{S}$, et al. Analysis of fractalkine receptor CX(3)CR 1 function by targeted deletion and green fluorescent protein reporter gene insertion. Mol Cell Biol 2000;20 4106-4114.

60. Hanna J, Bechtel P, Zhai Y, Youssef F, McLachlan K, Mandelboim O. Novel insights on human NK cells' immunological modalities revealed by gene expression profiling. J Immunol 2004;173: 6547-6563.

61. Wendt K, Wilk E, Buyny S, Buer J, Schmidt $\mathrm{RE}$, Jacobs R. Gene and protein characteristics reflect functional diversity of CD56dim and CD56bright NK cells. J Leukoc Biol 2006;80:1529-1541.

62. Beider $\mathrm{K}$, et al. Involvement of CXCR4 and IL-2 in the homing and retention of human NK and NK T cells to the bone marrow and spleen of NOD/SCID mice. Blood 2003 102:1951-1958.
63. Abraham M, et al. Enhanced unique pattern of hematopoietic cell mobilization induced by the CXCR4 antagonist 4F-benzoylTN14003. Stem Cells 2007; in press.

64. Jiang D, et al. Regulation of pulmonary fibrosis by chemokine receptor CXCR3. J Clin Invest 2004;114 291-299

65. Wald $\mathrm{O}$, et al. IFN-gamma acts on $\mathrm{T}$ cells to induce NK cell mobilization and accumulation in target organs. J Immunol 2006;176:4716-4729.

66. Widney DP, et al. CXCR3 and its ligands participate in the host response to Bordetella bronchiseptica infection of the mouse respiratory tract but are not required for clearance of bacteria from the lung. Infect Immun 2005;73:485-493.

67. Liu L, et al. Severe disease, unaltered leukocyte migration, and reduced IFNgamma production in $\mathrm{CXCR}^{-/}{ }^{--}$mice with experimental autoimmune encephalomyelitis. J Immunol 2006;176 4399-4409.

68. Cyster JG. Chemokines, sphingosine-1phosphate, and cell migration in secondary lymphoid organs. Annu Rev Immunol 2005;23:127-159.

69. Goetzl EJ, Rosen H. Regulation of immunity by lysosphingolipids and their $\mathrm{G}$ proteincoupled receptors. J Clin Invest 2004;114: 1531-1537.

70. Boos MD, Yokota Y, Eberl G, Kee BL. Mature natural killer cell and lymphoid tissueinducing cell development requires Id2mediated suppression of $\mathrm{E}$ protein activity. J Exp Med 2007;204:1119-1130.

71. Frey M, et al. Differential expression and function of L-selectin on CD56bright and CD56dim natural killer cell subsets. J Immunol 1998;161:400-408.

72. Chen S, Kawashima H, Lowe JB, Lanier LL, Fukuda M. Suppression of tumor formation in lymph nodes by L-selectin-mediated natural killer cell recruitment. J Exp Med 2005;202:1679-1689.

73. Ferlazzo G, et al. Distinct roles of IL-12 and IL-15 in human natural killer cell activation by dendritic cells from secondary lymphoid organs. Proc Natl Acad Sci USA 2004;101: 16606-16611

74. Mailliard RB, et al. IL-18-induced CD83+CCR7+ NK helper cells. J Exp Med 2005:202:941-953.

75. Mazo IB, et al. Bone marrow is a major reservoir and site of recruitment for central memory CD8 + T cells. Immunity 2005;22: 259-270.

76. Andre P, et al. Modification of P-selectin glycoprotein ligand-1 with a natural killer cell-restricted sulfated lactosamine creates an alternate ligand for L-selectin. Proc Natl Acad Sci USA 2000;97:3400-3405.
77. Ohmori K, et al. Differentiation-dependent expression of sialyl stage-specific embryonic antigen- 1 and I-antigens on human lymphoid cells and its implications for carbohydrate-mediated adhesion to vascular endothelium. Blood Article 1993;81: 101-111.

78. Yago T, et al. IL-12 promotes the adhesion of NK cells to endothelial selectins under flow conditions. J Immunol 1998;161: 1140-1145

79. Snapp KR, Ding H, Atkins K, Warnke R, Luscinskas FW, Kansas GS. A novel P-selectin glycoprotein ligand-1 monoclonal antibody recognizes an epitope within the tyrosine sulfate motif of human PSGL-1 and blocks recognition of both P- and L-selectin. Blood 1998;91:154-164.

80. Vivier E, et al. Developmental regulation of a mucinlike glycoprotein selectively expressed on natural killer cells. J Exp Med 1993;1 78:2023-2033.

81. Walcheck B, Moore KL, McEver RP, Kishimoto TK. Neutrophil-neutrophil interactions under hydrodynamic shear stress involve L-selectin and PSGL-1. A mechanism that amplifies initial leukocyte accumulation of P-selectin in vitro. J Clin Invest 1996;98:1081-1087.

82. Chen JP, et al. Dengue virus induces expression of CXC chemokine ligand 10/ IFN-gamma-inducible protein 10, which competitively inhibits viral binding to cell surface heparan sulfate. J Immunol 2006;177:3185-3192.

83. Hokeness KL, Kuziel WA, Biron CA, SalazarMather TP. Monocyte chemoattractant protein-1 and CCR2 interactions are required for IFN-alpha/beta-induced inflammatory responses and antiviral defense in liver. J Immunol 2005; 174:1549-1556.

84. Huang D, et al. The neuronal chemokine CX3CL1/fractalkine selectively recruits NK cells that modify experimental autoimmune encephalomyelitis within the central nervous system. FASEB J 2006;20 896-905.

85. Khan IA, et al. CCR5 is essential for NK cell trafficking and host survival following Toxoplasma gondii infection. PLoS Pathog 2006;2:e49.

86. Lavergne E, et al. Fractalkine mediates natural killer-dependent antitumor responses in vivo. Cancer Res 2003;63: 7468-7474.

87. Martin-Fontecha A, et al. Induced recruitment of NK cells to lymph nodes provides IFN-gamma for $\mathrm{T}(\mathrm{H}) 1$ priming. Nat Immunol 2004;5:1260-1265.

88. Morrison BE, Park SJ, Mooney JM, Mehrad B. Chemokine-mediated recruitment of NK cells is a critical host defense mechanism in 
invasive aspergillosis. J Clin Invest 2003; 112:1862-1870.

89. Salazar-Mather TP, Orange JS, Biron CA. Early murine cytomegalovirus (MCMV) infection induces liver natural killer (NK) cell inflammation and protection through macrophage inflammatory protein 1alpha (MIP-1alpha)-dependent pathways. J Exp Med 1998;187:1-14.

90. Stiles LN, Hardison JL, Schaumburg CS, Whitman LM, Lane TE. T cell antiviral effector function is not dependent on CXCL1 0 following murine coronavirus infection. J Immunol 2006;177: 8372-8380.

91. Wald O, Weiss ID, Galun E, Peled A. Chemokines in hepatitis $\mathrm{C}$ virus infection: pathogenesis, prognosis and therapeutics. Cytokine 2007; in press.

92. Yu YR, Fong AM, Combadiere C, Gao JL, Murphy PM, Patel DD. Defective antitumor responses in CX3CR1-deficient mice. Int J Cancer 2007;121:316-322.

93. Hanna J, et al. Functional aberrant expression of CCR2 receptor on chronically activated NK cells in patients with TAP-2 deficiency. Blood 2005;106:3465-3473.

94. Hanna J, et al. CXCL12 expression by invasive trophoblasts induces the specific migration of CD16 - human natural killer cells. Blood 2003;102:1569-1577.

95. Ramos MV, et al. Involvement of the fractalkine pathway in the pathogenesis of childhood hemolytic uremic syndrome. Blood 2007;109:2438-2445.

96. Sentman CL, Meadows SK, Wira CR, Eriksson M. Recruitment of uterine NK cells: induction of CXC chemokine ligands 10 and 11 in human endometrium by estradiol and progesterone. J Immunol 2004; 173:6760-6766.
97. Tacke F, et al. Monocyte subsets differentially employ CCR2, CCR5, and $\mathrm{CX} 3 \mathrm{CR} 1$ to accumulate within atherosclerotic plaques. J Clin Invest 2007; 117:185-194.

98. Tacke F, Randolph GJ. Migratory fate and differentiation of blood monocyte subsets. Immunobiology 2006;211:609-618.

99. Sallusto F, Lenig D, Forster R, Lipp M, Lanzavecchia A. Two subsets of memory T lymphocytes with distinct homing potentials and effector functions. Nature 1999;401:708-712.

100. Jin Y, Knudsen E, Wang L, Maghazachi AA. Lysophosphatidic acid induces human natural killer cell chemotaxis and intracellular calcium mobilization. Eur J Immunol 2003;33:2083-2089.

101. Pohajdak B, Gomez J, Orr FW, Khalil N, Talgoy M, Greenberg AH. Chemotaxis of large granular lymphocytes. J Immunol 1986;136:278-284.

102. Pilaro AM, Sayers TJ, McCormick KL, Reynolds CW, Wiltrout RH. An improved in vitro assay to quantitate chemotaxis of rat peripheral blood large granular lymphocytes (LGL). J Immunol Methods 1990;135:213-223

103. Bottazzi B, Introna M, Allavena P, Villa A, Mantovani A. In vitro migration of human large granular lymphocytes. J Immunol 1985; 134:2316-2321.

104. Bianchi G, et al. Migration of natural killer cells across endothelial cell monolayers. J Immunol 1993;151: 5135-5144.

105. Fong AM, et al. Fractalkine and CX3CR 1 mediate a novel mechanism of leukocyte capture, firm adhesion, and activation under physiologic flow. J Exp Med 1998;188: 1413-1419.
106. Wiltrout RH, et al. Augmentation of organassociated natural killer activity by biological response modifiers. Isolation and characterization of large granular lymphocytes from the liver. J Exp Med 1984;160:1431-1449.

107. Twilley TA, Mason L, Talmadge JE, Wiltrout RH. Increase in liver-associated natural killer activity by polyribonucleotides. Nat Immun Cell Growth Regul 1987;6:279-290.

108. Wang J, Xu JW, Zhang WC, Wei HM, Tian ZG. TLR3 ligand-induced accumulation of activated splenic natural killer cells into liver. Cell Mol Immunol 2005;2: 449-453.

109. Biron CA, Nguyen KB, Pien GC, Cousens LP, Salazar-Mather TP. Natural killer cells in antiviral defense: function and regulation by innate cytokines. Annu Rev Immunol 1999; 17:189-220.

110. Chen Y, Wei H, Gao B, Hu Z, Zheng S, Tian $Z$. Activation and function of hepatic NK cells in hepatitis B infection: an underinvestigated innate immune response. J Viral Hepat 2005;12:38-45.

111. Takeda K, Hayakawa Y, Van Kaer L, Matsuda H, Yagita H, Okumura K. Critical contribution of liver natural killer $\mathrm{T}$ cells to a murine model of hepatitis. Proc Natl Acad Sci USA 2000;97: 5498-5503.

112. Guarda G, et al. L-selectin-negative CCR7 ( - ) effector and memory CD8(+) $\mathrm{T}$ cells enter reactive lymph nodes and kill dendritic cells. Nat Immunol 2007;8:743-752.

113. Walzer $\mathrm{T}$, et al. Natural cell trafficking in vivo requires a dedicated sphingosine 1phosphate receptor. Nat Immunol; in press. 